\title{
A Profile of Master-Degree Program Graduates of Economic Education, UNNES: A Tracer Study
}

\author{
Kardoyo $^{1}$, Ahmad Nurkhin ${ }^{2}$, Inaya Sari Melati ${ }^{3}$ \\ ${ }^{1,2,3}$ Faculty of Economics, Universitas Negeri Semarang, Indonesia \\ ${ }^{1}$ Corresponding email: kardoyo@mail.unnes.ac.id
}

\begin{abstract}
Master-Degree Program in Economic Education UNNES is entering its eighth year in 2018. The study program's performance analysis has been conducted in 2017. Nevertheless, the field of alumni still needs further evaluation. This study aims to provide a comprehensive overview of the profile of graduates of the Master Degree Program in Economic Education UNNES. The research design is quantitative descriptive research. The object of research is graduates and users of graduates of the 2011-2015 class program. The variables studied were profile of graduates and graduate user evaluation. Methods of data collection used were questionnaires and interviews. Questionnaire method is done online through utilization of google form (google docs). Data analysis technique used is descriptive analysis. The results showed that most of the graduates of UNNES's master degree in economic education work as educators (teachers and lecturers), both in public and private schools/universities. Based on the amount of salary received, graduates earn about 3-5 million rupiah per month. Graduates acknowledge that their competencies are relevant to the needs of the workplace. The other result show that graduate user's express satisfaction with the competencies of the graduates. Graduate users also provide input for curriculum development.
\end{abstract}

Key words: graduate, user, profile, master-degree program in economic education UNNES

\section{Introduction}

Economic Education Program of PostGraduate UNNES has entered its eighth year since its establishment in 2011. The number of new students has been fluctuative every year. In the first generation (2011), there were 13 students, in 2012 were 24 students, in 2013 were 22 students, 2014 were 42 students, in 2015 were 29 students, 2016 were 23 students, and in 2017 were 15 students. Based on the data of the graduates number, the Master's Degree of Economics Education program has brought about as many as 78 graduates until April of 2018 or equal to $58 \%$ of the number of students who should have graduated. The number of students of 2011-2015 class is 130 people.

The accreditation obtained by Master's Degree Program in Economics Education of UNNES is B in 2014 and will expire in 2018 according to Decree of PT BAN No. 005/SK/BAN-PT/Akred/M/I/2014. The accreditation period will expire on January 9, 2019. The accreditation preparation period should start early and the effort that has been done is by doing some research of study program development. Research has been conducted to provide systematic input for the development of study program. Research in 2015 only focused on the quality of service. Result of research give recommendation to manager of study program to improve lecture quality. Students, alumni, and alumni users provide good constructive advice related to the curriculum and the availability of lecture facilities and infrastructure. In addition, they gave incisive sugestion on administrative and academic services for students (Kardoyo \& Nurkhin, 2016).

Research development of study program has been done in 2016-2017. Research in 2016 focused on the quality of lectures. The result of the research shows that the study program of Economic Education must improve the quality of lecturers and increase internet access as the main priority requirement based on requirement analysis that has been carried out (Kardoyo \& Nurkhin, 2017b). Research in 2017 showed performance evaluation of study program on the field of academic, student, graduates, and cooperation. Performance evaluation of graduates is expected to be continued through tracer study in a more comprehensive manner. The new tracer study activity was first conducted in 2015 (Kardoyo \& Nurkhin, 2017a). The next research that should be conducted is tracer study. Tracer study is a mechanism by various parties to trace alumni to measure the relevance of educational objectives and processes to current alumni conditions. Tracer studies appear in many terminology such as postgraduate research, advanced studies, alumni surveys, and follow-up surveys (Wibisono et al., 2012). In addition, Millington (2001) pointed out that "they provide quantitative structural data on occupations and careers, job 
characteristics and related competencies, and information about professional orientation, and experience of their graduates." (Gines, 2014).

According to guidelines for the preparation of arranging accreditation forms, there are evaluation items of graduates and graduate users (BAN-PT, 2009a; BAN-PT, 2009b). Tracer study is very important to implement. Graduate surveys provide rich experience about the whereabouts of graduates, which might help to broaden perspectives among administrators, faculty and students. Such information as the income, the economic sector, the current job title, the working duration, the values of development and practice in work (Hazaymeh \& Peña, 2017). Tracer study was perceived as useful to improve the learning process, market gauge (satisfaction, demand), and building alumni network (Pannogan \& Ocampo, 2016). An alumni database is a valuable information source for university development. However, alumni databases tend to be incomplete (Toba, Wijaya, Wijanto, \& Karnalim, 2017).

Fahriany, Musfah, \& Albantani (2014) stated that there were at least four reasons why the existence, contribution and role of alumni were important to be tracked and recorded. First, the success of alumni in society is the success of the study program. Second, the measurement of the vision and mission of the study program can be seen in the success of alumni in developing their profession in society, especially in educational institution. Third, the BAN PT University National Accreditation Board) of the Ministry of Research, Technology and Higher Education mandates the need for Tracer Study in one of the accreditation standards of the Department / study program is the student and alumni profile. And fourth, the existence of alumni database of study program is a must for study program evaluation based on self evaluation.

The focus of tracer study done by several researchers is quite diverse. Hazaymeh \& Peña (2017) tracked the profile of graduates with the competencies required for work and should be obtained during college. Fahriany et al. (2014) in his research on tracer study, focused on several aspects, such as the suitability of the professions occupied by alumni, the length of waiting period to obtain a job, absorption and contribution in education and social, socialintellectual mobility, and alumni achievement. Gines (2014) used CHED instruments to obtain biographical data of alumni and retrospective evaluation programs.
Abidin (2015) revealed the level of acceptance of alumni and alumni satisfaction on curriculum structure and lecture process in tracer study which has been done at universitas Islam Indonesia. Bakhtiar \& Latif (2017) conducted research on tracer study with focus of alumni profile, alumni waiting period, relevance study program with job market needs, and alumni user feedback.

Some techniques or methods are developed to improve the quality of tracer study. Wibisono, Ulama, \& Asmoro (2012) developed the Integrated Tracer Study System (ITSS) to improve the quality of data obtained in tracer study. This system applies two methods to improve the scope of tracer study. He was able to obtain extensive alumni data in a relatively limited time. Gines (2014) used two instruments to obtain data in alumni search, a questionnaire developed by CHED and using focus group discussion (FGD) methods. Khair, Astuti, \& Khairina (2016) developed a web-based tracer study system. It uses PHP and MySQL databases. The system can record the data well and through the website online alumni search activities can be done effectively and efficiently. The same thing was conducted by Rahardja, Tiara, \& Wulandari (2016) who developed the web for information media for alumni. Thus, tracer study will be easy to carry out.

Research on the graduate profile of the post-graduate program of Economic Education in UNNES is a more thoroughgoing study to provide an overview of graduate profile and graduate user evaluation. Graduates who involved in this research are graduates since the first generation (in 2011) until the fifth generation (in 2015). Graduate profiles will be described and analyzed to obtain a comprehensive evaluation for the development and improvement of the quality of education. Graduates user feedback and suggestions will also be well analyzed as a positive contribution for institutional development. The existence of alumni becomes very important for the development of study program.

The purpose of this study is as follows; (a) Analyze the Master's Degree graduates' profile of Economic Education UNNES; (b) Analyze the Master's Degree graduate's evaluation of Economic Education UNNES; and (c) Analyze the evaluation of Master's Degree graduate's user of Economic Education UNNES. 


\section{Methods}

\section{Research Design}

This research belongs to descriptive quantitative research. This research tries to give a description of a phenomenon quantitatively. This research is intended to describe the profile of graduates and the evaluation of graduate user of the graduate program of Post-Graduate Economic Education in UNNES more comprehensively. This research has been conducted in the Postgraduate Economic Education Program of UNNES for 4 (four) months, from April until July 2018.

\section{Population and Sample}

Population in this research are graduates and users of Master's Degree graduates of Economics Education, postgraduate program of UNNES year 2011-2015. All members of the population will be research respondents. The number of respondents in this study is 75 students and 75 graduates users (see table 1). The number of respondents will be increased if at the time of the research, there are students who have completed the graduation.

Table 1. Graduates of Master Program of Economic Education, Postgraduate UNNES

\begin{tabular}{ccc}
\hline No. & Year & Total of Graduate \\
\hline 1. & 2011 & 10 \\
2. & 2012 & 16 \\
3. & 2013 & 17 \\
4. & 2014 & 26 \\
5. & 2015 & 6 \\
\hline & Total & $\mathbf{7 5}$ \\
\hline
\end{tabular}

\section{Operational Definition of Research Variables}

The research variables were the profile of Master Program's graduates and graduate users. The operational definitions of the research variables were developed based on the instruments used by previous researchers on tracer study, including the instruments used by Hazaymeh \& Peña (2017). The evaluation of graduate users was developed based on guidelines for the preparation of accreditation forms issued by BAN PT. The operational definition of research variables is shown in table 2 below.
Table 2. Operational Definition of Research Variable

\begin{tabular}{|c|c|c|}
\hline No. & $\begin{array}{c}\text { The } \\
\text { Dimension of } \\
\text { Research } \\
\text { Variables } \\
\end{array}$ & Indicator \\
\hline 1. & $\begin{array}{l}\text { General } \\
\text { Profile of } \\
\text { Graduate }\end{array}$ & $\begin{array}{l}\text { a. Admission year } \\
\text { b. Graduation year } \\
\text { c. Address } \\
\text { d. Gender } \\
\text { e. Telephone number } \\
\text { f. E-mail Address }\end{array}$ \\
\hline 2. & $\begin{array}{l}\text { Employment } \\
\text { Profile of } \\
\text { Graduates }\end{array}$ & $\begin{array}{l}\text { a. Job status } \\
\text { b. Length of work } \\
\text { (duration) } \\
\text { c. Salary (monthly) }\end{array}$ \\
\hline 3. & $\begin{array}{l}\text { Graduates } \\
\text { Competence } \\
\text { Evaluation }\end{array}$ & $\begin{array}{l}\text { Competence and needs } \\
\text { relevance during work }\end{array}$ \\
\hline 4. & $\begin{array}{l}\text { Graduates' } \\
\text { user } \\
\text { Evaluation }\end{array}$ & $\begin{array}{l}\text { a. Identity } \\
\text { b. Graduates' competence } \\
\text { perception } \\
\text { c. Graduates' user advice }\end{array}$ \\
\hline
\end{tabular}

\section{Method of Data Collection}

The type of data used in this study is primary data. The study used a questionnaire method developed from instruments that have been used by previous researchers. Researchers use the application google docs (google form) to obtain data from research respondents spread in the region of Central Java in order to get the data quickly and completely.

\section{Method of Data Analysis}

Data analysis method used is descriptive statistical analysis. The analysis is a technique used to provide a more detailed description of the graduate profile and evaluation of graduate users. Each dimension of the variable will be described quantitatively based on data collection. Graduate profile analysis is done by describing respondent's characteristic, such as gender, batch, duration of work, origin, work institution, and other characteristics. Evaluation analysis of graduate user held descriptively to know the level of user satisfaction on the quality of graduates.

\section{Result and Discussion}

This research was conducted from April to July 2018. The instruments that have been compiled are then distributed through the google form application and disseminated its links through instant messaging applications, specifically WhatsApp. The total of graduates is 75 people who have been sent research instruments. However, not all graduates fill out the form or instrument of the study. Description of respondents can be seen in table 3. The 
number of graduates who fill this research instrument through google form application is as many as 23 people. Response rate of this research is $30.67 \%$. Table 3 shows that according to gender, the respondents are evenly distributed. Eleven people (47.83) of respondents were male, and 12 people $(52.17 \%)$ were female.

Based on the year of graduate's admission can be seen that the generation of 2011 became the largest respondents in this study, as many as 7 people $(30.43 \%)$. The next larger respondents came from the generation of 2013, which is $26.09 \%$. Based on the item of graduation year, most of the respondents came from the year graduated in 2015, which is 6 (26.09\%). Graduates of 2013 and 2018 become the next larger respondents, i.e. as many as 5 people or $21.74 \%$. This indicates that graduates have a high degree of concern and still communicate with the program managers well. Although they have graduated some years ago, there are still many respondents who are still willing to provide information and suggestions for the campus development.

Table 3. The Description of Research Respondents

\begin{tabular}{|c|c|c|c|}
\hline No & Description & Total & $\%$ \\
\hline \multirow[t]{4}{*}{1} & Gender & & \\
\hline & Male & 11 & 47.83 \\
\hline & Female & 12 & 52.17 \\
\hline & Total & 23 & $100 \%$ \\
\hline \multirow[t]{7}{*}{2} & Admission Year & & \\
\hline & 2011 & 7 & 30.43 \\
\hline & 2012 & 5 & 21.74 \\
\hline & 2013 & 6 & 26.09 \\
\hline & 2014 & 1 & 4.35 \\
\hline & 2015 & 2 & 8.70 \\
\hline & Total & 23 & $100 \%$ \\
\hline \multirow[t]{8}{*}{3} & Graduation Year & & \\
\hline & 2013 & 5 & 21.74 \\
\hline & 2014 & 3 & 13.04 \\
\hline & 2015 & 6 & 26.09 \\
\hline & 2016 & 1 & 4.35 \\
\hline & 2017 & 3 & 13.04 \\
\hline & 2018 & 5 & 21.74 \\
\hline & Total & 23 & $100 \%$ \\
\hline
\end{tabular}

Graduate Profile of Master Degree Program in Economic Education
Table 4 illustrates the distribution of graduate profiles by job type. Graduates of Master Program in Economic Education work in the field of education entirely (school or college), by becoming teacher, overseer, principal, or lecturer. Most of them are working in public schools than in private schools and more graduate employment status is civil servant (PNS). Most graduates work as high school teachers, as many as 10 people or $44 \%$. The next profession is university lecturers; 4 people or $17 \%$. The junior high school teacher becomes the next larger profession, that is $13 \%$. In addition, graduates work as school overseer $(4 \%)$, principals $(4 \%)$, vocational teachers $(9 \%)$, and PTS lecturers (9\%).

Tabel 4. Graduate Profile by Job Type

\begin{tabular}{lcc}
\hline \multicolumn{1}{c}{ Job Type } & Total & Percentage \\
\hline $\begin{array}{l}\text { Elementary school } \\
\text { teacher }\end{array}$ & 3 & 13 \\
$\begin{array}{l}\text { Senior high school } \\
\text { teacher }\end{array}$ & 10 & 43 \\
$\begin{array}{l}\text { Vocational high school } \\
\text { teacher }\end{array}$ & 2 & 9 \\
Principal & 1 & 4 \\
School overseer & 1 & 4 \\
Public university lecturer & 4 & 17 \\
Private university lecturer & 2 & 9 \\
\hline \multicolumn{1}{c}{ Total } & $\mathbf{2 3}$ & $\mathbf{1 0 0}$ \\
\hline
\end{tabular}

A graduate profile based on the length of work is shown in figure 1 . There are many as 9 graduates or $39 \%$ who have worked as long as $11-20$ years. A total of 8 people (35\%) graduates who work less than 5 years. Only 1 person has worked for more than 20 years. A total of 5 people (22\%) have worked between 5-10 years. Graph 2 gives the meaning that the graduates have enough experience, because averagely they have been working more than 5 years. Graduates consider the right time to pursue their master degree before the "golden age" is passed.

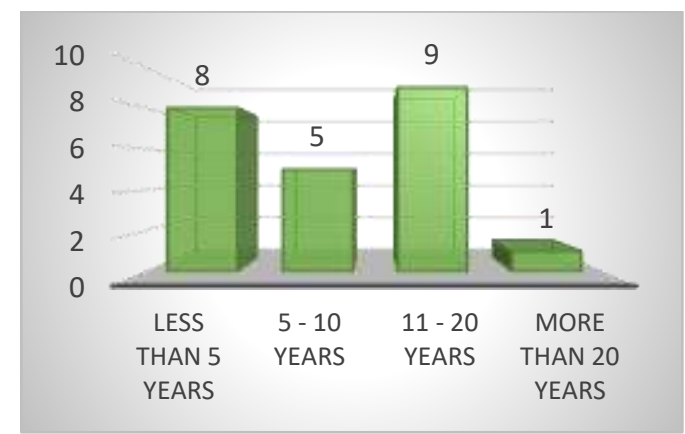

Figure 1. Graduate Profile Based on Length of Work 
The next graduate profile is based on the monthly salary received. Figure 2 provides information that most graduates or as many as 15 people $(65 \%)$ receive a monthly salary of approximately 3.5 to 6 million rupiah per month. Seven people $(31 \%)$ received a salary of approximately 1.5 to 3.5 million per month. Only 1 person (4\%) received a salary of more than 6 million. This indicates that the salary received by the graduate of the Master Program of Economics Education UNNES has met the standard salary in general or UMR (regional minimum wage). Graduates are concentrated in Central Java, especially in Semarang City and surrounding areas.

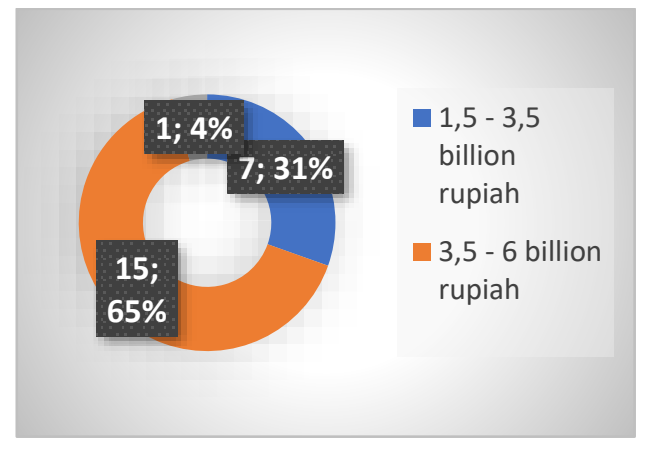

Figure 2. Profile of Graduates Based on Monthly Salary Received

\section{Evaluation of master's Degree Graduates in Economic Education Program UNNES}

Graduates are also given the opportunity to provide an evaluation to the study program. The item of statements include the relevance of knowledge and skills acquired during the study with the field of work. Includes advice on soft skills needed to support graduate occupation. The results of the evaluation of the graduates are presented in Table 5. Most of the alumni respond that the material obtained during the study has been susceptible (relevant) to the field of work currently involved. Based on respondents' answers it is known that most of the alumni propose entrepreneurship courses (business feasibility studies) and research methodology as well as scientific publications. Public relations skills, learning technology development skills, entrepreneurship skills, and research skills as well as scientific publications become the skills that most alumni recommend.
Table 5. Graduate Evaluation

\begin{tabular}{|c|c|}
\hline Item & $\begin{array}{c}\text { Summary of Alumni } \\
\text { Evaluation }\end{array}$ \\
\hline $\begin{array}{l}\text { Relevance of the } \\
\text { material obtained } \\
\text { during the study of } \\
\text { current work }\end{array}$ & 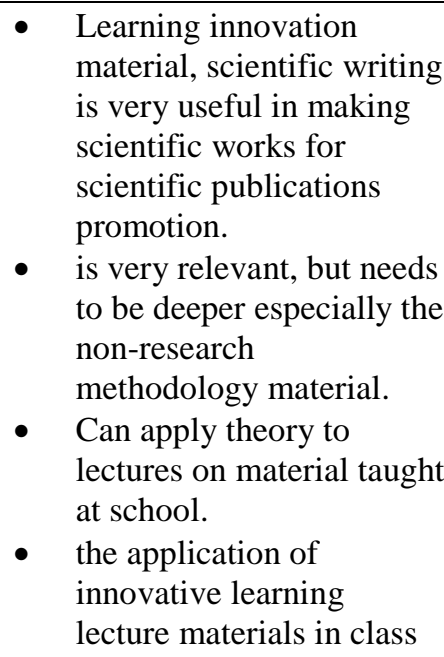 \\
\hline $\begin{array}{l}\text { Learning } \\
\text { Proposed Courses }\end{array}$ & $\begin{array}{l}\text { - } \\
\text { bustrepreneurship and } \\
\text { - } \\
\text { capital market } \\
\text { - } \text { management information } \\
\text { system applications in } \\
\text { education } \\
\text { - } \quad \text { education funding } \\
\text { - } \quad \text { classroom action research } \\
\text { and scientific publications }\end{array}$ \\
\hline $\begin{array}{l}\text { Sugestions for the } \\
\text { Required Skills }\end{array}$ & $\begin{array}{l}\text { Business management and } \\
\text { Communication Skills } \\
\text { (public relations) } \\
\text { Skills to develop } \\
\text { knowledge through } \\
\text { scientific publications / } \\
\text { innovative works that } \\
\text { support sustainable } \\
\text { professional development } \\
\text { activities. } \\
\text { Entrepreneurial skills, } \\
\text { because currently the } \\
\text { world is really need of } \\
\text { reliable entrepreneurs to } \\
\text { get out of the wave of the } \\
\text { economic crisis } \\
\text { Technology skills } \\
\text { (research and learning) }\end{array}$ \\
\hline
\end{tabular}

\section{Graduate User Evaluation of Master's Degree Program of Economic Education, UNNES}

The evaluation of graduate user used instruments that is developed from guidelines for the preparation of accreditation forms of BAN PT. There are 9 evaluation items, namely integrity, professionalism, insight, leadership, foreign language, communication, technology use, and self-development. The evaluation of 
graduate users can be seen in table 6 . According to graduate users, graduates generally have excellent competence. Competence of professionalism of graduates obtained a very good assessment, that is as much as $65 \%$. Mastery of a foreign language become an evaluation item that obtains less than the maximum assessment of graduate users. Only 5 people $(22 \%)$ graduates are considered to have foreign language skills very well.
Graduate users also give general comments to the alumni. Graduate users state that graduates have high integrity, responsibility toward their profession, good and extensive knowledge, and have high morale. Graduate users also reckon that UNNES is the best campus capable of creating graduates in education.

Table 6. Evaluation of Graduate Users

\begin{tabular}{cllccccc}
\hline \multirow{2}{*}{ No. } & \multirow{2}{*}{ Graduate Evaluation Item } & \multicolumn{2}{c}{ Very good } & \multicolumn{2}{c}{ Good } & \multicolumn{2}{c}{ Fair } \\
& F & \multicolumn{1}{c}{ F } & F & \\
\hline 1. & Integrity (ethics and morals) & 12 & 52 & 11 & 48 & 0 & 0 \\
2. & $\begin{array}{l}\text { Mastery of knowledge } \\
\text { (professionalism) }\end{array}$ & 15 & 65 & 7 & 30 & 1 & 4 \\
3. & Science insight & 14 & 61 & 8 & 35 & 1 & 4 \\
4. & Leadership & 11 & 48 & 11 & 48 & 1 & 4 \\
5. & Teamwork & 12 & 52 & 11 & 48 & 0 & 0 \\
6. & Foreign language & 5 & 22 & 15 & 65 & 3 & 13 \\
7. & Communication & 13 & 57 & 9 & 39 & 1 & 4 \\
8. & The use of information & 10 & 43 & 13 & 57 & 0 & 0 \\
9. & Sechnology & 12 & 52 & 11 & 48 & 0 & 0 \\
\hline
\end{tabular}

\section{Discussion}

Based on the type of work, most of the respondents are teachers. This is very natural, because the main objective of the study program is the teacher. Teachers desperately need the development of professionalism through further study. Study program of post graduate program of Economic Education is considered to be the right choice with expectation, graduates will gain increased knowledge and skills. Study program managers are expected to always evaluate the curriculum and learning process that accommodate the needs of teachers, especially high school/ MA/ SMK teachers. It must be a concern that the needs of high school teachers with vocational school is different. The development of the study program through the provision of concentration choises become alternative policy in the future. Thus, the study program can expand the student's target and will be a choise for high school / MA / SMK teachers. Study Program of post graduate of Economic Education increasingly growing in the region of Central Java and Yogyakarta. Therefore, it should be well anticipated.

Some of alumni of economic education UNNES have been working for about 11-20 years, although most of them have just worked less than 5 years. It means that alumni have had enough experience in work and have good ability and skill. This should be considered by the management of the study program to be able to conduct good quality lectures. Lecturers can present to invite students to be more interactive in solving the actual problems, both in the field of education and others.

Graduates also provide evaluation for the development of study program. Although graduates have declared the suitability of lecture materials to the needs of work, graduates provide some sugestions. This will certainly be a consideration for the manager of the study program. The proposal for the addition and development of course content becomes very important, especially in curriculum development. The need to face the industrial revolution and the development of digital business should be well anticipated. Graduates have provided sugestion on the importance of business and entrepreneurship courses as well as information technology skills. Graduates of the Master Program of Economics Education in the future should be able to master information technology according to the needs of learning in the classroom and should be able to develop ideas and creativity. 
Evaluation of graduate user needs to be closely viewed, especially foreign language skills. Graduates are considered to lack of foreign languages (English), whereas this ability is very important for the development of learning in the classroom. Because most of the graduates are teachers and lecturers. Improved foreign language skills may be made through the minimum requirements of the TOEFL score. Hopefully, students will be aware and seriously improve their English skills through the course and others. Support the implementation of English language lectures are also expected to motivate students to continue to improve its ability. English should be considered a necessity.

The ability of information technology becomes the next competence that get the evaluation score less than the maximum of graduate users. Mastery of information technology is very important to deal with students who are millennial generation, which is very dependent on the gadget owned. The ability of internet access is very high. Graduates who become teachers and lecturers should be able to catch this challenge. Learning innovation should be able to start from lecturing and supported by emphasising utilization of information technology. Project awareness (project-based learning) should be developed in lectures to improve skills and skills in information technology, such as the development of multimedia-based, android, and internet-based learning media.

Graduates should be familiar with presentation software other than Microsoft power point. Graduates should be introduced to other applications such as PowToon, Prezi, and others. More important, however, is to shape the graduate mindset to be open and passionate in developing information technology-based learning. Innovative ideas must come from graduates, although technically development can be through more competent parties. The feedback from this user is consistent with the advice given by the graduate.

\section{Conclusion}

The profile of graduate of the Master Program of Economics Education UNNES can be seen from the type of work, occupation, length of work, and the amount of salary received. Graduates who become respondents in this research work in the field of education, as teachers, principals, overseers, and lecturers. Most of the graduates work as senior high school/vocational school teachers. Most of them has worked for more than 10 years and has received a salary of about 3-6 million rupiah per month.

Graduates also provide an evaluation for the study program by providing suggestions for additional courses or improvement of lecture materials, especially in business and entrepreneurship, mastering information technology and innovation in the field of learning, as well as research and publication skills.

Graduate users give an excellent appraisal for the graduate. Graduate users feel satisfied and assume that graduates have integrity, responsibility, spirit of work and have adequate competence. Nevertheless, there are several evaluation items that need to be considered for improvement, such as foreign language skills and mastery of information and communication technology.

\section{References}

Abidin, M. (2015). Alumni Satisfaction on Curriculum Structure And Learning Process in Indonesian Islamic University. International Journal of Scientific Research And Education, 3(2), 2900-2905.

Bakhtiar, M. I., \& Latif, S. (2017). Tracer Study Alumni: Upaya Pengembangan Prodi Bimbingan Konseling Universitas Negeri Makassar. Jurnal Kajian Bimbingan Dan Konseling, 2(1), 32-40. Retrieved from http://journal2.um.ac.id/index.php/jkbk.

BAN-PT. (2009a). Buku 1- Naskah Akademik Akreditasi Program Studi Magister. Jakarta: BAN PT.

BAN-PT. (2009b). Buku 2-Standar Dan Prosedur Akreditasi Program Studi Magister. Jakarta: BAN PT.

Fahriany, Musfah, J., \& Albantani, A. M. (2014). Profil sosial intelektual alumni program magister FITK UIN Syarif Hidayatullah Jakarta. Jakarta.

Gines, A. C. (2014). Tracer Study of PNU Graduates. American International Journal of Contemporary Research, 4(3), 81-98.

Hazaymeh, E. N. M., \& Peña, M. K. Dela. (2017). A Tracer Study of La Salle University College of Engineering Graduates. Lasallian Research Forum, 18(1), 52-68.

Kardoyo, \& Nurkhin, A. (2016). Analisis Kepuasan Pelayanan Perguruan Tinggi (Kasus pada Prodi Magister Pendidikan Ekonomi Unnes). Cakrawala Pendidikan, XXXI(02), 164-175.

Kardoyo, \& Nurkhin, A. (2017a). Analisis 
Kinerja Prodi Pendidikan Ekonomi S2 PPs UNNES menuju Akreditasi Unggul. Semarang.

Kardoyo, \& Nurkhin, A. (2017b). Improving Learning Quality using Needs Analysis. The Social Science, 12(12), 2338-2343.

Khair, M., Astuti, I. F., \& Khairina, D. M. (2016). Alumni Tracer System berbasis web (study kasus Fakultas Matematika dan ilmu pengetahuan Alam). In Prosiding Seminar Sains dan Teknologi FMIPA Unmul (pp. 471-475). Samarinda: FMIPA Universitas Mulawarman.

Pannogan, O. C., \& Ocampo, D. P. (2016). Tracer study of bachelor of arts graduates major in English. International Journal of Advanced Research in Management and Social Sciences, 5(1), 281-297.

Rahardja, U., Tiara, K., \& Wulandari, L. S. (2016). Penerapan Web Alumni Sebagai
Penunjang Media Informasi Pada Perguruan Tinggi Raharja. In Seminar Nasional Teknologi Informasi dan Multimedia 2016 (pp. 6-7). Yogyakarta: STMIK AMIKOM Yogyakarta.

Toba, H., Wijaya, E. A., Wijanto, M. C., \& Karnalim, O. (2017). Enhanced unsupervised person name disambiguation to support alumni tracer study. Global Journal of Engineering Education, 19(1), 42-48.

Wibisono, A., Ulama, B. S. S., \& Asmoro, W. A. (2012). Tracer Study At Institut Teknologi Sepuluh Nopember (ITS), Promoting Localization and Multiple Touch Points To Capture Alumni. In International Conference on Experience with Link and Match in Higher Education: Result of tracer studies world wide (pp. 19). Denpasar. 